\title{
PEMBINAAN KOMPETENSI PEDAGOGIK GURU SD PEMBANGUNAN LABORATORIUM UNIVERSITAS NEGERI PADANG
}

\author{
Oleh: Zuliarni \\ FIP Universitas Negeri Padang
}

\begin{abstract}
Zuliarni, 2016. “Competence Development Pedagogic Elementary School Teacher Development Laboratory of the State University of Padang”. Thesis, Graduate Program, State University of Padang.

Results of the study revealed that mastery of pedagogical competence of teachers is low, characterized by the manufacture of RPP result of the adoption PL and prepared students for the purposes of surveillance, media and methods are still conventional, low-grade teaching is not thematic. Development of pedagogical competence of teachers is not yet optimal. Coaching by the school principal is done through classroom observation, meetings with teachers, and the assignment of teachers to follow KKG. Coaching by a senior teacher of the junior teachers in the form of a discussion or share teaching experience, as well as self-learning teachers. Constraints in coaching comes from internal and external. Effort in overcoming the obstacles in the guidance is advised teachers to continue their education to $S 1$ as well as participate in various training, teacher performance assessment, contact the UNP to provide training to teachers in order to improve teachers' pedagogical competence. This study suggested that the acquisition and development of pedagogical competence of elementary school teachers UNP Development Laboratory can be improved through training and on going coaching to produce learning and quality education.
\end{abstract}

Keywords : pedagogical, Whole Brain Teaching.

\section{PENDAHULUAN}

Perubahan-perubahan kurikulum sangat mempengaruhi perubahaan dalam proses pengembangan proses pembelajaran agar tujuan kurikulum dapat tercapai. Perubahan ini tentunya juga berkaitan erat dengan perlunya peningkatan kualitas kompetensi pedagogik guru dalam upaya merencanakan pembelajaran didalam kelas. Dengan terjadinya perubahan kurikulum, maka segala sesuatu yang berkaitan dengan perencanaan pembelajaran akan mengalami perubahan, dan guru dituntut untuk memahami penjabaran kurikulum dalam bentuk perencanaan pembelajaaran di kelas. Banyak hal yang dapat dilakukan dalam upaya membantu guru dalam meringankan tugas ini. Dalam hal ini pemerintah telah melakukan berbagai upaya antara lain meningkatkan kompetendi pedagogik guru melalui seminar, lokakarya, penataran, pembentukan kelompok kerja guru, pusat pengembangan guru, izin belajar serta meningkatkan kesejahteraan guru. Sebagian guru dengan ataupun tanpa fasilitas dari pemerintah juga sudah mengikuti berbagai aktivitas untuk meningkatkan profesionalitasnya seperti seminar, lokakarya dan mengikuti pendidikan dengan biaya sendiri.

Berdasarkan observasi awal pada tahun 2010 di SD Pembangunan Laboratorium UNP Kota Padang ditemui berbagai fenomena berkaitan dengan penguasaan kompetensi pedagogik guruguru yang mengajar di sekolah tersebut. Hasil observasi didapat informasi bahwa guru tidak membuat rencana persiapan pengajaran. Berdasarkan hasil wawancara awal dikatakan bahwa faktor penyebab di antaranya guru kurang mampu memahami tehnik pembuatan rencana persiapan pengajaran. Guru yang menyatakan kurang mampu menjabarkan kurikulum ke dalam hal yang lebih operasional yakni pembuatan RPP. Banyak guru mengaku bahwa cukup sulit membuat 
RPP dan kebanyakan hanya menyalin contoh yang telah tersedia. Kesulitan guru dalam melaksanakan tugas merancang RPP ini memberikan peluang kemungkinan adanya tenaga yang membantu menyelesaikan RPP guru yang difungsikan hanya untuk administrasi, bukan pada fungsi utamanya.

Berdasarkan latar belakang dan fenomena yang telah dikemukakan sebelumnya, maka fokus penelitian dalam penelitian ini adalah untuk mengkaji tentang Bagaimana Pembinaan Kompetensi Paedagogik Guru SD Pembangunan Laboratorium UNP Padang.

\section{METODOLOGI PENELITIAN}

Penelitian ini menggunakan metode penelitian kualitatif dengan pendekatan deskriptif. Metode dipilih berdasarkan pertimbangan bahwa penelitian ini akan berupaya untuk mengungkapkan bagaimana penguasaan kompetensi pedagoggik guru dan pembinaan oleh kepala sekolah di SD Pembangunan UNP Padang. Sebagaimana yang dikemukakan oleh Moleong (2009:6) bahwa penelitian kualititatif bermaksud untuk memahami fenomena tentang apa yang dialami oleh subjek peneliti secara mendalam dan realistis pada suatu konteks khusus yang alamiah.

Lokasi penelitian adalah SD Pembangunan UNP Padang. Sekolah ini dipilih sebagai tempat penelitian karena sekolah ini merupakan bimbingan Yayasan Pendidikan dan Kesejahteraan KORPRI UNP yang memang telah lama membina pendidikan mulai dari SD sampai SMA.

Informan kunci dalam penelitian ini adalah para guru dan Kepala Sekolah SD Pembangunan Laboratorium UNP Padang.

Dalam teknik penjaminan keabsahan data, peneliti mengacu pada teori standar kredibilitas menurut Sanapiah (1990:31) yaitu: Standar kredibilitas diperlukan supaya hasil penelitian dapat dipercaya oleh para pembaca dan juga dapat disetujui oleh partisipan yang diteliti. Cara-cara yang dilakukan adalah sebagai berikut:

1. Tidak tergesa-gesa dalam mengambil data sebelum tercipta raport waktu kegiatan penelitian di lapangan.
2. Melakukan observasi secara terus-menerus dan sungguh-sungguh selama jangka waktu tertentu sehingga informasi yang diperoleh apa adanya atau asli.

3. Membandingkan data hasil pengamatan dengan wawancara serta informasi dari informan dilakukan konfirmasi dengan informan lain.

4. Melibatkan teman sejawat yang tidak ikut dalam penelitian.

5. Melaksanakan analisis kasus negatif dengan jalan menguji ada tidaknya kasus atau keadaan yang bisa menggugah kebenaran temuan/ hasil penelitian sehingga dapat hasil yang tidak terbantah lagi.

6. Melacak kesesuaian segenap hasil analisis data dan bila semakin sesuai, bahkan bisa saling menjelaskan satu sama lain maka penelitiannya semakin terpercaya.

7. Mencek kesesuaian rekaman, interpretasi, dan kesimpulan-kesimpulan hasil penelitian dari para partisipan selama penelitian berlangsung dengan jalan meminta kepada mereka mereview dan mencek kebenarannya.

\section{HASIL PENELITIAN DAN PEMBAHASAN}

\section{Penguasaan Kompetensi Pedagogik Guru}

Berdasarkan temuan khusus yang didapat, diketahui bahwa penguasaan kompetensi pedagogik guru rendah. RPP dibuat guru hasil adopsi dari mahasiswa yang PL di sekolah tersebut dan dibuat untuk keperluan pengawasan, metode yang digunakan terpusat pada guru, media yang digunakan masih konvensional, guru kelas rendah tidak melaksanakan pembelajaran tematik serta pengelolaan kelas oleh guru yunior menemui kesulitan.

Kemampuan membuat perencanaan pembelajaran merupakan langkah awal yang harus dimiliki oleh guru sebelum melaksanakan proses pembelajaran, karena perencanaan ini adalah muara dari pengetahuan teori, keterampilan dasar, dan pemahaman tentang peserta didik serta situasi pembelajaran. Cynthia dalam Mulyasa (2006:174) menyatakan: 
Proses pembelajaran yang dimulai dengan pengembangan rencana pembelajaran, ketika kompetensi dan metode telah diidentifikasikan, akan membantu guru dalam mengorganisasikan materi pembelajaran, serta mengantisipasi peserta didik dan masalah-masalah yang mungkin timbul dalam pembelajaran. Sebaliknya tanpa rencana pembelajaran, seorang guru akan mengalami hambatan dalam proses pembelajaran.

Sesuai dengan hasil penelitian dimana guru tidak mempersiapkan rencana pembelajaran sebelum pembelajaran dilakukan dan ketidak mampuan guru membuat sendiri tentu saja dapat berakibat tidak lancarnya proses yang dilakukan, pembelajaran bisa tidak terarah yang selanjutnya berpengaruh pada pencapaian tujuan pembelajaran.

Guru SD Pembangunan masih menggunakan media yang konvensional, seperti papan tulis dan buku paket, media yang ada tidak digunakan sebagaimana mestinya, guru lebih cenderung menggunakan papan tulis sebagai alat bantu mengajar. Guru seharusnya memahami bahwa penggunaan media dalam pembelajaran sangat bermanfaat, ada beberapa manfaat penggunaan media dalam pembelajaran dikemukakan oleh Wina (2010:171):

a. Media dapat mengatasi keterbatasan pengalaman yang dimiliki siswa.

b. Media dapat mengatasi batas ruang kelas.

c. Media dapat memungkinkan terjadinya interaksi langsung antara peserta didik dengan lingkungan

d. Media dapat menghasilkan keseragaman

e. Media dapat menanamkan konsep dasar yang benar, nyata, dan tepat.

f. Media dapat membangkitkan motivasi dan merangsang peserta didik untuk belajar dengan baik.

g. Media dapat membangkitkan keinginan dan minat baru.

h. Media dapat memberikan pengalaman menyeluruh dari hal-hal yang konkret ke abstrak.

Dari pendapat di atas dapat disimpulkan bahwa penggunaan media dapat memberikan pengalaman nyata bagi peserta didik tanpa penggunaannya pelajaran menjadi verbalis, abstrak, dan sulit dipahami.

Selain komponen metode dan media dalam pembelajaran, guru perlu mempedomani kurikulum yang sedang berlaku. Kurikulum adalah pedoman bagi guru dalam melaksanakan pembelajaran agar lebih terarah. Setiap penyempurnaan atau perubahan kurikulum, terjadi pula perubahan pada pembelajaran. Pelaksanaan kurikulum KTSP untuk kelas rendah menggunakan sistem tematik, namun yang dilaksanakan di SD Pembangunan Laboratorium UNP masih melaksanakan sesuai materi pelajaran bukan berdasar tema. Alasan yang diberikan oleh guru adalah karena tidak konsisten antara pelaksanaannya dengan sistem penilaian. Soal yang dibuat untuk penilaian berdasarkan mata pelajaran karena pengisian nilai pada rapor bukan menurut tema tetapi masih menurut mata pelajaran.

\section{Upaya Pembinaan Kompetensi Pedagogik Guru SD Pembangunan Laboratorium UNP Padang}

Berdasarkan dari hasil penelitian yang dilakukan berkaitan dengan pembinaan kompetensi pedagogik guru, diketahui bahwa usaha pembinaan yang dilakukan oleh Kepala Sekolah, adalah; mengadakan rapat, observasi kelas, penugasan guru untuk KKG, dan melakukan penilaian atas kinerja guru. Pembinaan yang dilakukan guru berupa kerjasama antara guru yang lebih senior kepada guru yunior, yaitu berbagi pengalaman tentang mengajar. Selain yang dikemukakan di atas, guru juga melakukan kegiatan atas inisiatif guru sendiri, seperti belajar sendiri, membaca berbagai literature yang gunanya untuk peningkatan penguasaan kompetensinya. Namun pembinaan yang dilakukan tidak berdampak banyak pada perbaikan pembelajaran yang dilakukan guru. Penampilan kompetensi pedagogik guru belum mampu menghasilkan pembelajaran yang berkualitas apalagi menjadikan SD Pembangunan sebagai sekolah Laboratorium UNP memiliki kualitas yang lebih baik. Pembinaan yang dilakukan seharusnya membawa 
perubahan kearah yang lebih baik, tidak terjadi pembinaan kalau tidak ada perubahan. Mulyasa (2004:156) menyatakan "pembinaan seharusnya menyebabkan perbaikan atau peningkatan kemampuan profesional guru." Kepala Sekolah sebagai Pembina guru di sekolah harus mengusahakan pembinaan yang intensif bagi guru agar semua guru menjadi guru yang profesional.

Agar usaha pembinaan mendapatkan hasil yang efektif perlu memperhatikan berbagai prinsip sebagai pedoman atau arah yang penting dalam menjalankan pembinaan. Ada beberapa prinsip yang dapat dipedomani dalam melakukan pembinaan yang merupakan pekerjaan supervisi, Gwynn dalam Bafadal (2003:46) mengemukakan beberapa prinsip dari supervisi, yaitu:

a. Supervisi harus mampu menciptakan hubungan kemanusiaan yang harmonis

b. Supervisi harus dilakukan secara berkesinambungan

c. Supervisi pendidikan harus demokratis

d. Program supervise pendidikan harus komprehensif

e. Supervisi pendidikan harus kontruktif

f. Supervisi pendidikan harus objektif.

Dalam melaksanakan pembinaan kompetensi pedagogik guru akan dapat maksimal hasilnya apabila dalam pelaksanaannya guru juga diberi informasi tentang Penilaian Kinerja Guru (PKG). Adapun informasi tentang PKG ini akan dapat memberikan motivasi guru dalam meningkatkan kompetensi pedagogiknya. Menurut Peraturan Menteri Negara Pendayagunaan Aparatur Negara dan Reformasi Birokrasi Nomor 16 Tahun 2009, PK GURU adalah penilaian dari tiap butir kegiatan tugas utama guru dalam rangka pembinaan karir, kepangkatan, dan jabatannya.

\section{Kendala-Kendala dalam Pembinaan Kompetensi Pedagogik Guru SD Pembangunan Laboratorium UNP}

Upaya pembinaan kompetensi pedagogik guru di SD Laboratorium Pembangunan UNP oleh Kepala Sekolah maupun guru-guru menemui beberapa kendala, baik yang bersifat internal maupun eksternal. Kendala yang bersifat internal berasal dari guru-guru yaitu sebagian guru yang mengajar adalah guru honor yang tidak tetap dan kurang pengalaman. Mereka mengajar hanya sementara menjelang pengangkatan jadi PNS. Keadaan ini sedikit banyak mendatangkan kesulitan bagi sekolah untuk memiliki guru professional. Pembinaan yang diberikan kepada mereka bersifat sementara menjelang pengangkatan mereka menjadi PNS sehingga manfaat dari pembinaan tersebut tidak dapat dirasakan untuk waktu yang lama.

Kendala berikut adalah sebagian guru tidak disiplin menjalankan tugasnya, misalnya ketika pembuatan RPP mestinya bisa diawal semester tetapi kadang-kadang malah sebaliknya. Padahal disiplin sangat penting untuk ditegakkan, Mulyasa (2004:118) menyatakan: "Disiplin merupakan sesuatu yang penting untuk menanamkan rasa hormat terhadap kewenangan, menanamkan kerjasama, dan merupakan kebutuhan untuk berorganisasi, serta untuk menanamkan rasa hormat terhadap orang lain". Sedangkan kendala yang bersifat eksternal adalah kurangnya perhatian dari Yayasan UNP sebagai lembaga yang berkepentingan dalam penyelenggaraan pendidikan di sekolah melakukan kegiatan pembinaan kompetensi pedagogik guru berupa pelatihan maupun penataran Demikian pula dalam kelengkapan sarana terkadang guru harus mengusahakan sendiri.

\section{Usaha-usaha Mengatasi Kendala dalam Pembinaan Kompetensi Pedagogik Guru SD Pembangunan Laboratorium UNP}

Pada pembahasan sebelumnya telah dikemukakan bahwa ada beberapa kendala yang dihadapi oleh Kepala Sekolah maupun guru dalam pembinaan kompetensi pedagogik. Hasil penelitian menunjukkan beberapa usaha yang dilakukan Kepala Sekolah untuk mengatasi kendala tersebut, yaitu; melakukan supervisi pada saat guru melakukan kegiatan pembelajaran, mendukung ide ide baru dari guru, mengadakan rapat dengan guru 
untuk membahas masalah pembelajaran, mengawasi tugas guru untuk meningkatkan disiplin kerja, serta melakukan penilaian terhadap tugas guru. Selain beberapa usaha tersebut, usaha lainnya yang telah dilakukan adalah Kepala Sekolah menghubungi Yayasan untuk mau membantu pembinaan ini. Sehubungan dengan usaha pembinaan ini ada banyak pihak yang berperan aktif seperti yang diungkapkan A, Cece, Wijaya, (1991: 22) sebagai berikut:

\section{Guru dan KKG/MGMP}

Guru yang tersebar di seluruh Indonesia masing-masing perlu mendapatkan akses untuk berkumpul membentuk kelompok sesuai dengan interes profesionalnya masing-masing.

\section{Satuan Pendidikan}

Fungsi satuan pendidikan dalam kaitannya dengan pengembangan profesional guru, merupakan tempat yang sangat vital dalam pengembangan guru. Seluruh perangkat dan infrastruktur sekolah dapat digunakan oleh para guru dalam proses peningkatan profesionalnya.

\section{LPMP dan P4TK}

Dalam upaya menumbuh kembangkan KKG dan MGMP, perlu mendapatkan pasokan informasi, material dan juga finansial secara sistematis. Lembaga yang dapat memberikan masukan di antaranya Lembaga Penjaminan Mutu Pendidik (LPMP) dan Pusat Pengembangan dan Pemberdayaan Pendidik dan Tenaga Kependidikan (P4TK). Keberadaan LPMP dan P4TK memiliki peran yang sangat penting dalam pengemangan karier guru untuk meningkat profesional guru itu sendiri.

4. Perguruan Tinggi

Lembaga perguruan tinggi mempunyai peranan signifikan dalam meningkat dan mengembangan kemampuan guru. Perguruan tinggi dapat melakukan kegiatan-kegiatan di satuan-satuan pendidikan guna ikut mengaktifkan guru-guru dan menjalin hubungan kerja sama pengembangan pendidikan.

5. Asosiasi Profesi

Asosiasi dapat bekerja sama dalam mengerakkan dinamika guru dengan berbagai macam kegiatan yang mengarah pada pemberdayaan individu dan kelompok guru.

6. Kepala Sekolah dan Pengawas atau KKS/MKK $\mathrm{S}, \mathrm{KKP} / \mathrm{MKPS}$

Secara real di daerah-daerah, kepala sekolah dan pengawas yang bergabung dalam KKS/MKKS dan KKP/MKKPS mempunyai fungsi sangat menentukan bagi pengembangan profesional guru. Kepala sekolah dan pengawas dapat berperan positif terhadap pengembangan guru.

\section{SIMPULAN DAN SARAN \\ Simpulan}

Berdasarkan hasil penelitian yang telah dilakukan di SD Pembangunan Laboratorium UNP tentang pembinaan kompetensi pedagogik guru, dapat disimpulkan sebagai berikut:

1. Penguasaan kompetensi pedagogik guru SD Pembangunan Laboratorium UNP masih rendah. Hal ini didasarkan pada temuan penelitian yaitu: RPP yang dibuat guru adalah hasil adopsi dari RPP mahasiswa PL kependidikan, sebagian guru membuat RPP tersebut karena adanya pemeriksaan oleh kepala sekolah bukan untuk keperluan pembelajaran. Metode dan media yang digunakan masih konvensional yaitu metode yang terpusat pada guru dan media papan tulis. Pelaksanaan kurikulum pada kelas rendah seharusnya bersifat tematik namun dilaksanakan berdasarkan mata pelajaran. Sebagian guru mengalami kesulitan mengelola kelas di saat pembelajaran berlangsung.

2. Pembinaan kompetensi pedagogik guru SD Pembangunan Laboratorium UNP masih belum optimal. Pembinaan dilakukan oleh kepala sekolah dan guru senior terhadap guru junior. Pembinaan oleh kepala sekolah terhadap guruguru antara lain: mengadakan rapat dengan guru, observasi kelas, penugasan guru untuk mengkuti KKG. Sedangkan pembinaan guru senior terhadap guru junior berupa diskusi/ berbagi pengalaman tentang pengelolaan kelas dalam pembelajaran. 
3. Pembinaan kompetensi pedagogik guru SD Pembangunan Laboratorium UNP mengalami kendala baik dari internal maupun eksternal. Kendala yang bersifat internal antara lain: sebagian guru yang mengajar adalah guru honor/guru tidak tetap, pola pikir guru yang masih konvensional, pengalaman mengajar guru terbatas serta kurangnya disiplin guru dalam menjalankan tugas. Kendala eksternal adalah perhatian yang minim dari pihak yayasan UNP terhadap pelaksanaan pembinaan kompetensi pedagogik guru.

4. Usaha yang telah dilakukan oleh kepala sekolah dan guru untuk mengatasi kendala yang dihadapi dalam pembinaan kompetensi pedagogik antara lain: saran oleh kepala sekolah terhadap guru yang masih berijazah D2 untuk melanjutkan pendidikan ke program sarjana tanpa mengganggu aktivitas mengajar di sekolah. Menyarankan kepada guru untuk mengikuti berbagai pelatihan guna meningkatkan penguasaan kompetensi pedagogiknya. Menghubungi pihak yayasan, dosen UNP, serta lembaga pengabdian masyarakat agar dapat membantu memberikan pelatihan kepada guru-guru terkait dengan kompetensi pedagogik.

Dari beberapa kesimpulan yang telah dijelaskan di atas implikasinya yaitu:

a. Kompetensi pedagogik Guru SD Pembangunan Laboratorium UNP masih rendah, akibatnya proses pembelajaran di kelas kurang terarah karena tidak didasarkan pada perencanaan yang ada. Pembelajaran bersifat monoton, keterlibatan siswa kurang karena metode yang digunakan guru cenderung berpusat pada guru. Media yang digunakan masih konvensional sehingga pembelajaran kurang menarik dan bersifat abstrak padahal siswa di sekolah dasar memiliki kemampuan berfikir pada taraf konkrit.

b. Pembinaan kompetensi pedagogik guru SD Pembangunan belum optimal sehingga guruguru jadi kurang kompeten mengelola pembelajaran terutama dalam merancang pembelajaran yang berkualitas, serta melaksanakan pemebelajaran yang efisien dan efektif.

c. Yayasan UNP seharusnya memberikan perhatian yang memadai untuk meningkatkan kompetensi pedagogik guru sehingga SD Pembangunan sebagai sekolah laboratorium UNP memiliki guru-guru yang berkompeten di bidang pedagogik yang akhirnya kualitas pendidikan menjadi lebih baik.

\section{Saran}

Berdasarkan kesimpulan yang telah diuraikan di atas, peneliti menyarankan:

1. Semua guru hendaknya mempersiapkan RPP sebelum mengajar dengan menggunakan media yang berorientasi pada siswa serta menggunakan media dalam proses pembelajaran.

2. Yayasan UNP hendaknya memfasilitasi guruguru untuk mengikuti pelatihan tentang merancang pembelajaran menurut kurikukulum yang berlaku, berbagai strategi pembelajaran serta media pembelajaran di bawah pengawasan Kepala Sekolah.

3. Kepala sekolah hendaknya melakukan pembinaan secara intensif, berkelanjutan dan menjalin kerja sama dengan dosen-dosen UNP, melalui Lembaga Pengabdian Masyarakat untuk menjadikan SD Pembangunan sebagai labor untuk melatih guru-guru dalam penguasaan kompetensi pedagogik guru.

4. Kepada para pengawas pendidikan hendaknya lebih mengoptimalkan kegiatan kepengawasannya terutama berkenaan pembinaan tenaga pendidikan (guru)

5. Kepada instansi terkait Dinas Pendidikan Daerah maupun propinsi bahkan UNP hendaknya secara kontinu dan intensif mengupayakan berbagai bentuk pendidikan, pelatihan maupun penataran bagi guru-guru.

\section{DAFTAR PUSTAKA}

A, Cece, Wijaya.1991. Kemampuan Dasar Guru Dalam Proses Belajar Mengajar. Bandung: PT Remaja Rosda Karya 
Da'i Wibowo. 2009. Pengaruh Supervisi Kepala Sekolah dan Kompetensi Guru Pedagogik Guru Terhadap Kinerja Guru SD Negeri Kecamatan Kersana Kabupaten Brebes. Skripsi Tidak Dipublikasikan.

Depdiknas. 2006. Standar Kompetensi Kepala Sekolah TK, SD, SMP, SMA, SMK \& SLB, Jakarta: BP. Cipta Karya

Ibrahim, Bafadal. 2003. Peningkatan Profesionalisme Guru Sekolah Dasar dalam Kerangka Manajemen Mutu Berbasis Sekolah. Jakarta: Bumi Aksara

Lexy Moleong. 2009. Metodologi Penelitian Kualitatif. Bandung: Remaja Rosdakarya

Made Pidarta, 2009, Supervisi Pendidikan Konstektual, Jakarta: Rineka Cipta

Maunah, Binti. 2009, Supervisi Pendidikan Islam Teori dan Praktek, Yogyakarta: Sukses Offset

Miles, Matthew B dan Huberman, A. Michael. 2009. Analisis Data Kualitatif. Terjemahan. Jakarta: UI Press
Nana Sudjana. 2008. Supervisi Akademik, Membina Profesionalisme Guru melalui Supervisi Klinis. Binamitra Publishing.

Piet A. Sahertian. 2000, Konsep Dasar dan Teknik Supervisi Pendidikan dalam Rangka Pengembangan Sumber Daya Manusia. Jakarta: Rineka Cipta.

Sanapiah, Faisal. 1990. Penelitian Kualitatif: Dasa r-Dasar Aplikasi. Malang: Yayasan Asah Asih Asuh.

Sugiyono. 2004. Memahami Penelitian Pendidikan. Bandung: Alfabeta.

Syaiful Sagala. 2010. Supervisi Pembelajaran dalam Profesi Pendidikan. Bandung : Alfabeta

Wahyudi. 2012. Kepemimpinan Kepala Sekolah dalam Organisasi Pembelajar. Bandung: Alfabeta

Wina Sanjaya. 2010. Strategi Pembelajaran Berorientasi Standar Peoses Pendidikan. Jakarta: Kencana. 